\title{
Reintegration And Socio-Economic Transformation For Ex Combatants Of The Free Aceh Movement (Gam) Post-Conflict Era In North Aceh-Indonesia
}

\author{
M. Nazaruddin', Nirzalin², Cut Sukmawati³, Abdullah Akhyar Nasution ${ }^{4}$ \\ Department of Sociology 12 \\ Department of Public Administration ${ }^{3}$ \\ Department of Anthropology 4 \\ Faculty of Social and Political Science, Malikussaleh University \\ Lhokseumawe, Aceh, Indonesia \\ mnazaruddin1973@gmail.com ${ }^{1}$,nirzalinarmia@yahoo.co.id ${ }^{2}$,cutsukmawati1978@gmail.com³, \\ 4n4st.ime@gmail.com ${ }^{4}$
}

\begin{abstract}
This research has found several facts, including: (1) The motivation that drives the former GAM combatant build a "Koperasi" of oil palm plantations such as: the spirit of togetherness, a feeling as communities affected by conflict and marginalized communities who must also feel more prosperous life, responding to the MoU and to fill peace and to enjoy a better life for Aceh's people. Motivation is also encouraged because the government does not serving them by similar programs, as a moral responsibility to Ex-GAM combatants, widow and the orphans of victims of conflict and other marginalized communities. (2) On the durability of an organization that despite the shortage; the sense of responsibility of the manager of the "koperasi" and run effective communication, leadership of democratic system, government subsidies and financial support from "Sagoe". To understand (verstehen) and to find the meaning of the viewpoint and the appreciation of GAM combatants as manager of "koperasi" palm oil "Bumoe Tari" and the people affected by the conflict as beneficiaries of the "koperasi", in this study researches using qualitative methods. Observation, interviews, documentary studies and focus group discussions (FGD) were used as a method of data collection. Analysis and interpretation of data is done interactively.
\end{abstract}

Keywords: Reintegration, Organization, motivation, Socio-economic welfare, Ex GAM Combatants and Conflict Victims, North Aceh, Indonesia.

\section{INTRODUCTION}

Various post-conflict peace studies in many countries indicated that post-armed conflict peace is vulnerable to reoccur in the same vortex of conflict with a more intense and deeper complexity. Although not easy, the success of transformation of socioeconomic welfare of ex combatants and conflict victims bring sustainable and true peace as shown by Scandinavian countries, Brazil and India. Thus, the key of permanent, stabilised and sustainable peace lies in the successful reintegration of ex combatants and the change in their welfare level as well as the victims from the communities.This reality reinforces the belief that the most substantial homework after peace is to transform socio- economic welfare of ex combatants and civilian conflict victims (Olle Tornquist, 2011: 578).

Reintegration program and transformation of social welfare is generally managed by outsiders of conflict actor both central or local governments, national and international non-governmental organizations. However, in Simpang Keuramat North Aceh, the actor of reintegration and economic welfare transformation of ex combatants and conflict victims is drived by the conflict actor himself, a.e. the ex commander of the Free Aceh Movement in Tengku Chiek Di Lhoek Moen Simpang Keuramat, M. Dahlan who well known as Mak Lan. 
The process of reintegration and economic welfare transformation for ex combatants and conflict victims is carried out by ex GAM combatants through the establishment of joint venture called Cooperative of Bumoe Tari.Through this cooperative, the empowerment of economic welfare for ex combatants and conflict victims are managed systematically. The final goal is to improve economic welfare of ex GAM combatants and conflict victims so that reintegration of ex combatants into society goes naturally and social issues arising from the traumatic effects of conflict victims can be handled properly.

Through Cooperative of Bumoe Tari, ex GAM combatants built their prosperity by opening palm oil business. In fact, palm oil is not only an effort to improve the socioeconomic welfare but also a medium of ex combatants integration into society. It seems there is transformative symptom where in the past the social and political power of GAM was mobilized to the interests of political fight against the government of Indonesia (M. Nazaruddin, 2011: 412). However, the current social and political power of GAM is mobilized to improve the welfare and reintegration of ex combatants into civil society.

Theoretically, the process of empowerment contains two tendencies. The first is called primary tendency, namely, the empowerment that emphasise on the process of giving or diverting some power, strength or ability to the community to become a more empowered individual. This process can be equipped with an effort to build material asset to support the development of community self-reliance through organization. The second is called secondary tendency, namely, the emphasis on stimulating, encouraging or motivating process of individual to have ability or empowerment to determine his life choice through a process of dialogue (A.M.W Pranaka and Vidhyadika Moeljarto, 1996: 5657).

In the case of the empowerment of ex combatants and conflict victims that managed by ex GAM commander in Teungku Chiek Di Moen Lhoek Simpang Keuramat North Aceh, both empowering processes run simultaneously so that both are primer.

\section{RESEARCH METHODS}

This study is a qualitative research as Alvesson argue (2000) that seeks to understand (verstehen) and grasp the meaning of ex GAM combatants's viewpoints and experiences as managers of "Bumoe Tari" palm oil cooperative.Therefore, the perspective used in understanding the phenomenon in this study is a phenomenological perspective (Atkitson, Paul, dkk (eds). 2001). Objectivity in this perspective method is built on the formulation of specific situations as lived by individuals or particular social group (Moleong: 2000), which in this study are the ex combatants. The process is important because what appears on the surface as a pattern of human action is the radiance of what is in the human mind (Faisal: 2003)

The data in this study were obtained from the initiators of the establishment of the cooperative, managers and workers as well as community leaders and beneficiaries of palm oil plantation by Cooperative of Bumoe Tari Simpang Keuramat. Data collection techniques as Blaikie (2000) suggested included observation, indept interview, Focus Group Discussion (FGD) and documents analysis

\section{SOCIAL CONTEXT OF BUMOE TARI COOPERATIVE}

Cooperative of palm oil plantation was founded by ex GAM combatants in Sagoe ${ }^{1}$ Tgk. Chiek Di Mon Lhoek Simpang Keuramat North Aceh, named Cooperative of Bumoe Tari. The main objective of the establishment of this cooperative is an effort to increase social and economic welfare of the members, the conflict victims and other marginal

\footnotetext{
${ }^{1}$ Sagoe (Acehnese) is an area like sub-district level. Sagoe led by a sagoe commander. This territorial term is popularized again by GAM.
} 
groups in the territory.

In addition, the initative to form a group in Bumoe Tari Cooperative was driven by their awareness that the process of social reintegration of ex combatants and conflict victims become one of very crucial agenda for the continuation of a lasting peace in Aceh. In fact, social reintegration program of ex combatants and conflict victims is one clause in the MoU (Memorandum of Understanding) of Helsinki, Finland that must be realized by the Government of Indonesia (the central government).

So, the establishment of palm oil plantation cooperative is also at the same time responding to the MoU to empower ex GAM combatants, conflict victims and poor people in Aceh. In accordance with the MoU, ex GAM combatants will be given a decent job in this case can be interpreted as giving plantation land to them. This is actually an important clause in the MoU to establish peace in Aceh.

But, in reality it was not realized. When referring to the $\mathrm{MoU}$, the responsibility to carry out this matter is in the hand of the central government. It is not clear where it was constrained. So, apart from that, the GAM combatants in the region initiated and moved on their own to realize the mandate of the MoU.

Then, they began to make in roads for the implementation of the work.They began to search for arable land that can be used for plantation. They also made trading business of rubber latex in which they used the profits for the interest of the members and conflict victims. While the venture capital from this trade was derived from training program funds conducted to their members by other party. The funds were then gathered and used as initial venture capital and it was only around Rp. 90.000.000.

Then, they initiated to integrate their activities with Bumoe Tari Cooperative. It is understood that the activities they do, especially the opening of palm oil plantation can be legal, can provide more benefit to more people and can maintain the cohesiveness and a sense of kinship that they felt during the conflict.

So, the momentum of the peace also serves as a moment for ex GAM combatants in Sagoe Tgk. Chiek Di Mon Lhok to prove that their existence does have many benefits for society at large, and conflict victims in particular and more particularly for widows and orphans of conflict whose husband and father had passed away on the battle field during the conflict (Antony Reid, 2006 : 155).

Cooperative of Bumoe Tari is the hope for ex GAM combatants and conflict victims to reach more prosperous, equitable, independent and dignified life together.There are many social and economic activities programs they have already undertaken through the Cooperative of Bumoe Tari as initial steps of tangible manifestation effort for their alignments to the public.

Until now they have land for palm oil plantation around 1.425 hectares. In early stage in 2008 they worked on a land of about 300 hectares. But, they managed to plant approximately 150 hectares. The rest was still in the form of a grove. But at the time of research they were clearing land for planting palm in new land they already have. In terms of membership, to date there are about 2963 families who has been the member of the cooperative.

Of the 150 hectares, a plantation plot in the name of each member has not been distributed to the members of the cooperative. What has been done is the yields of the plantation were used for maintenance and development of plantation. In addition, the yields were also used for urgent need of the members. It it usually for food, children's school fees, social land, health costs of the members and it is managed by the cooperative.

The initiator and cooperative management is not only from GAM combatants in Sagoe Tgk. Chiek Di Mon Lhok Simpang Keuramat North Aceh but also conflict victims and social issues observers. The elaboration of management not only has made the plantation cooperative run but also indicated that there has been a process of social integration of ex-combatants with the 
society. During the conflict, the elaboration was utilized for the benefit of Aceh's struggle for independence. But in this era of peace, the elaboration has been directed to empower a better social and economic life.

So, there is a transformation pattern of thought and action of GAM ex-combatants and the other people that were directed before to the political activities to fight the central government. Now, it is directed against marginality and other socio-economic helplessness.

\section{MOTIVATION FOR ORGANIZING PALM OIL PLANTATION}

Peace making is a difficult job, but it is much more difficult to maintain and manage the peace.The adage is not groundless because the reality shows how conflict areas tend to reoccur with a new, deeper and entrenched conflict after peace is agreed in paper by the actors of war (Tornquist, 2011: 135). Agreeing on peace can be done easily by the parties when the agreement acomodating respective interests are achieved. But, it becomes very difficult to keep a commitment, behavior and mentality of peace for actors in practical-empirical level, so that peace is not only true today but also tomorrow and forever.

Two fundamental intolerable things felt by ex combatants when they have to change their mentality from military into civilian after peace was proclaimed are first to deconstruct military mentality to civil mentality and second to make ends meet through the process of thought and sweat not in instant. Military mentality is a black and white mentality in which action is based on a clear line of command and not to consider many aspects of act let alone to have to negotiate with various interests of other parties. If self and ideological group need has met then action can be realized. Civil mentality is totally different.

Thought, consideration and wisdom become the core of any action being taken or not. There is no line of command much less black and white truth; all is relative. Only conscience guides someone in the act.
Wisdom is needed in order to put appropriate measures in complex and dynamic social sphere circle. Being civilian means ready to become a person who dare to take a risk. The risk of action in case it causes condemnation. Not for military, military personal is a safe personal. His actions are not accountable personally but the rules are responsible.

Fulfilling needs for military life is fast or instant. Institution where military serves will fulfill all their needs at any time. If it cannot be fulfilled, by snapping the weapon they could easily force the civilians to provide for them, moreover, if the military is a group that is involved in the war. It is in contrast to the civilian. No one fulfill his need but himself. The civilian will die of hunger if he is not creative and doing the process to think and to sweat to fulfill the necessities of life. For civilian ends meet requires a process, struggle, creativity and intelligence of the mind.

Contradictory reality of military and civilian mentality is always in a strict and rigorous dialectic in the minds of the combatants after the peace. If the dialectic ends with failure of combatants to adapt them selves to civil life then it is certainly that peace will not only be threatened but back over to the old conflict but with a deeper, sharp and severe nuance and quality. Conversely, if the combatants are able to internalize the new mentality, which is the civil mentality, the peace is certain to continue and even to last.

A vulnerable and fragile peace was realized by DI, a ex GAM commander in sagoe Teungku Chiek Di Moen Lhok Simpang Keuramat North Aceh. This GAM commander is still very young but intelligent, thoughtful and visionary. His attitude to support lasting peace in Aceh is shown by his earnest effort and care for peace itself. For DI, peace can only exist if ex-combatants successfully integrate themselves in civil society. Integration will occur and be permanent when ex-combatants can obtain welfare after surrendering their weapons to be destroyed during the declaration of peace. Without welfare, civil mentality transformation for ex- 
combatants will not be meaningful because the difficulties of life will encourage them back into the military and guerillas (Tim Kell, 1995: 73).

Welfare can be achieved if the ex combatants have job and steady income. Departing from this awareness, DI initiated economic empowerment to ex combatants for their prosperous and being integrated into society (Lukman Thaib, 2002: 105). A noble attitude and it reflects a true leader. If DI were pragmatic, he did not need to think about the interests of his ex subsidiaries since it is the duty of the country as it is written explicitly in Helsinki MoU on August 15, 2005. Also, after peace, they are no longer his responsibility. As a ex commander he could use the momentum of peace and also the momentum of Aceh government in which today are owned by ex-combatants by becoming contractors of government development projects, as commonly practiced by other ex commanders.

DI consistently clings to the ideological doctrine outlined by the founder of GAM, Wali Hasan Tiro (1981), "The people of Aceh have to live gloriously and not live as slaves (lamiet). Noble life means independent life... that's the base of the glory, prosperity and progress.Then, the people of Aceh must be unanimous (sapeu pakat) and live and die together (hudep sare mate Sajan, sikrak shroud saboh keurenda) (Tengku Hasan Tiro, 1984: 75). The ideological doctrine by the Wali of Aceh makes DI no longer see himself as individuals but he translates himself as part of the overall Acehnese who have to live together both in difficulty and prosperity. However, it is not enough to only prosper the ex-combatants. In order for life to get better and prosperity can be achieved together, DI invited orphans and conflict vitims as well.

DI, said:

"...In order to be prosperous, communities must be empowered, especially their economic capabilities.Therefore, the economic well-being will have an impact on various aspects either health, education or spiritual.The weakest among the poor is conflict-affectedorphans and widows. So I am remember very well the message of the Wali "take care of orphans", do not forget them. The message is primarily aimed at our members of GAM and this message that I want to achieve. I want the welfare of orphans and widows."2

Then DI gathered ex combatants, orphans and conflict victims to discuss the process of forming an organization to empower their economies. Organizationally, empowerment made through the cooperative while the model of empowerment through palm oil plantation. DI mentioned:

"So my friends and I formed cooperative of "Bumoe Tarie "which focuses on palm oil plantation. In addition to the welfare of excombatants, the cooperative also distribute the income for orphans, especially in Simpang Keuramat..."3

Palm oil was chosen based on practical considerations that the people have become accustomed to plant this tree. This facilitates the implementation process because they are already quite familiar; so no need any related training. The technical capabilities needed by the people involved are related to how the selection of superior seedlings, maintenance and fertilization. Economically, this tree has a high economic level with the production period to 25 years. Marketing is also very easy because in North Aceh there are many palm oil factories that are ready to accommodate any output generated.

For DI and his friends, the empowerment process as an integration effort cannot be postponed. Because waiting for the government to do it is uncertain yet again the capabilities of the government is limited. Objectively, up to mid-2015 the central government has not fully succeeded in realizing the reintegration program. Until now it is not clear where the problem that make the reintegration program constrained. The problem of reintegration of ex combatants is a very complex issue for the government related to the limited ability of the budget, management and data issue of the number of ex combatants. In reality, data on the number of ex combatants is far more than 3000 people, as formally agreed in the

\footnotetext{
${ }^{2}$ Interview With Mak Lan on March 28, 2015

${ }^{3}$ Interview with Om On March 28, 2015
} 
Helsinki MoU 2005. For GAM people in the field, they even said it is up to 60.000 people. And that's not including sympathizers and conflict victims.

When referring to the data of 3000 GAM recognized in the Helsinki MoU then this will lead to complicated problems in the field, especially on the distribution of 2 hectares of plantation for each of ex combatants from the 3000 people. Like in Sagoe Tgk. Chiek Di Mon Lhok, only about 5 ex-combatants is recognized, while in fact they are more or less 500 people. Not to mention the reintegration funding given to the ex combatants of 3000 people. Similar to the case to provide decent jobs for ex combatants and conflict victims, a striking difference between the data that is recognized by the government with the objective-empirical reality is very disturbing. If it is forced, those who feel not elligle to receive the right will be jealous with those who are registered and recognized by the government. This reality becomes a dilemma for the government and also for ex combatants themselves.

So, the political reintegration program as recognized by the MoU, even if it runs according to the mandate, itwould lead to new conflicts among ex GAM combatants and conflict victims because the program will create a new social jealousy that could cause significant horizontal conflict between them on one side and the conflict victims on the other side.

Therefore, ex GAM combatants in Sagoe Tgk.Chiek Di Mon Lhok made in roads along the way to overcome the social issues that will arise. The sagoe commander, DI is the most decisive person in this case. He feels he does not deserve anything of this peace if the people and the victims do not get any. Even the reintegration fund of Rp. 25.000.000 that only once he has ever received was distributed to all of his members who urgently needed it.

The attitude of altruism shown by DI becomes a source of example for other excombatants in Simpang Keuramat. While for conflict victims it becomes the basis of a charismatic aura from the commander in their eyes so that they follow him sincerely. In other context, a good and charismatic personality of the commander becomes the basis for solidity growth among ex combatants, orphans and conflict victims in the cooperative of Bumo Tarie. The reality of the complexity of problems faced by the government in the reintegration and doctrinal ideological desire to change the fate of his people pushed DI to work hard to realize his plans with friends and other concerned parties.

Then they began to make breakthrough to resolve the issue. They began searching for arable forest for plantation. They also made trading business of rubber latex in which the profits they utilized for the purposes of community members and victims of the conflict. While the venture capital from this trade was derived from training program funds done to their members by the other party. The funds were then gathered and used as initial venture capital only around $\mathrm{Rp}$. 90.000.000. From then, their initiative grew to integrate their activities with Cooperative of Bumoe Tari. It is understood that the activities they did, especially the opening of palm oil plantation has legality so it can provide more benefit to more people and can maintain the cohesiveness and a sense of kinship during the conflict that they already felt.

So, the momentum of peace also served as a moment for ex GAM combatants in Sagoe Tgk.Chiek Di Mon Lhok to prove that their existence does have many benefits for society at large, and conflict victims in particular and more particularly for widows and orphans of conflict whose husband and father had been passed away in the battle field during the conflict.

Cooperative of Bumoe Tari becomes hope for them to reach more prosperous, equitable, independent and dignified life together with ex GAM combatants and conflict victims. The trouble the people faced especially the poor in Simpang Keuramat in meeting basic needs in their lives such as health, education and others also triggered social care of DI and friends of ex combatants 
to care and be involved to resolve their problems. However, it took awhile for the intention to help be realized because funds to support the process of service was not available.

Thus, the Cooperative of Bumoe Tari is directed also to be able to support the process of social services of the community. Then, when palm oil plantation under the management of Cooperatives of Bumoe Tari started earning in about 15 hectares of the 150 hectares that have been planted, the yields were used for social interests ${ }^{4}$. In connection with the social services, they provided to the victims of conflict and the poors for both cooperative members and not members.

In FGD that we did, it is revealed that the form of social services they have offered such as: school supplies for orphans of conflict victims and other orphans, aid cash for the poor who had urgent needs both conflict victims and not conflict victims, health services for the poor both conflict victims and not conflict victims, meugang meat (In Aceh this tradition will be held one day before fasting month and one day before iedul fitri and iedul adha celebrate day) three times a year to all conflict orphans, conflict widows and the poor, envelopes (money stuffed into envelopes) Rp. 50.000 per orphan per meugang, envelope to all conflict widows around Rp. 200.000 per meugang, subsidy for 400 families of orphans Rp. 200.000 each month.

In connection with the information about social services, the participants of $\mathrm{FGD}^{5}$ said that they had been paying attention to the people who had urgent needs that they could not afford. For orphans and the poor, we bought school bags and other things, they said. But this is not a routine only when there is money. The main thing, we served aid to sick people. We have an ambulance ready to take people to the clinic or hospital in North Aceh and Banda Aceh, if they should be

\footnotetext{
${ }^{4}$ Interview with IR, Cooperative Management Bumoe Tari June 6, 2015

${ }^{5}$ FGD held on May 5, 2015
}

referred to there. Even last year, in Punge Banda Aceh we rented a house for the family who accompany patients for treatment in Banda Aceh. But, this year we cannot rent the house anymore because of limited funds. Ambulance service for the sick to hospital, we still do it until now, not only in Simpang Keuramat but also in Buloh and Nisam sub district of North Aceh.

While the same thing was also said by RB that because of the yields of the plantation, we now have two medicine depots and two health practitioners to treat the poor community. There is one ambulance and a car for social purposes. In the past, we also had a rental house to accommodate the sick people who are referred to Banda Aceh as a transit home. According to RB, this idea is from DI when he went to a hospital in Banda Aceh and he saw people in the hospital was like a refuge camp. When asked where they are from, they came from various areas in Aceh who went to Banda Aceh to get treatment but had no place to stay for the families who take care of sick people.

In $\mathrm{FGD}^{6}$ it is also revealed that they also provided meugang meat to conflict victims and the poor. For 3 times a year, we need about 1.5 billion to buy meugang meat for orphans, conflict widows and the poor, they said. Source of funds was the money from palm oil plantation and trading profit from latex done by the Sagoe.

In addition, we provided $2 \mathrm{~kg}$ of meugang meat per family for conflict orphans, DI said. We also provided envelopes (money of 50 thousand/person/meugang). The women whose husband died in the conflict also received it. If we get 200 thousand, they also get 200 thousand. We consider the money as a tribute to their late husband who died in the struggle.

Even, DI said, since last 5 years we also subsidized orphans 200 thousand per month (400 families). Initially, only conflict orphans but now since the orphans from the conflict continues to decrease, we also subsidize nonconflict orphan in our Sagoe. We are sad to

${ }^{6}$ FGD was held on May 30, 2015 
see their fate. This is actually the responsibility of the government but the government does not do anything, DI said. At this level, what they actually do is to take over the responsibility and role of the country for the people.

Besides, it was also revealed in the FGD about some people who get subsidized treatment from the cooperative, AY, 30 years, SP Keuramat; AKW, 42 years, Simpang Peut; MM, 30 years old, Kebon Baro. They have been referred to Zainal Abidin hospital in Banda Aceh several times by sagoe operational vehicles (sagoe ambulance). The cost was insured by the sagoe through the cooperative. The life cost of the care give from the family was also subsidized in Banda Aceh. The families also lived in a rented house provided by sagoe for the purposes of the patient's family in Banda Aceh. Likewise, the orphans were getting help for school needs. Two children of the late AS, meunasah Dayah SP Kramat; RK, son of the late DA, Keude SP Peut. They received school uniforms, bags and shoes.

What unfolds above shows that the presence of Cooperative of Bumoe Tari managed by Sagoe Tgk Chiek Di Moen Lhok has successfully opened palm oil plantation although step by step given the capital limitations they had. To open the plantation, the managers did not collect fees from the members considering they are of very marginal communities.

Besides, the yields of the plantations will be distributed to each memberfor 2 hectares. At the moment, they have been doing a lot of different kinds of social services to marginalized communities and especially conflict victims. Their presence in this context, especially in filling and strengthening community empowerment can be said as to fill the gap that has minimal touch from the country. Even with a different language, it can be said that their presence in this context has taken over the functions and duties of the country to empower people that the poor and abandoned children are supposed to be maintained by the country. In Sagoe Tgk. Chiek Di Moen Lhok, the task is now taken over by ex combatants in the Cooperative of Bumoe Tari.

Strong social integration of ex GAM combatants and communities in Simpang Keuramat has developed a close relationship between ex combatants and communities. Here, the presence of ex combatants who are concerned about various issues faced by the society has spawned a new reality that the people would rather hear the appeal of ex combatants than other actors including the government in many areas. In political sphere, the close emotional bond between the community and GAM was exploited by ex combatants to direct the public to vote for a party, members of the legislative and regent and governor elections.

In 2012 election, ex-combatants managed to direct the public to choose the figures that they wanted for political offices. The victory of Partai Aceh (PA/ex-Free Aceh Movement Party)), which is the party of ex combatants, was nearly $100 \%$ in this region? In the process of determining the figure chosen in the elections, the ex GAM combatants in Teungku Chiek Di Moen Lhoek who manages the Cooperative of Bumoe Tari consider the figures who give a firm commitment to support sustainable community development through cooperative of Bumoe Tarie in Kampung Keuramat. Here, the law of symbiotic mutualism applied in public vote. The chosen figures provided convenience and political and economic assistance to the community through Cooperative of Bumoe Tarie ${ }^{8}$.

Public loyalty towards ex combatants affiliated to Cooperative of Bumoe Tarie also indicated by their faithful to choose Partai Aceh in the elections in Aceh, although the party of the ex combatants in legislative elections in 2012 has been divided into Partai Aceh and Partai Nasional Aceh. It is because the ex combatants in Sagoe Teungku Chiek Di Moen Lhoek who manage the Cooperative of Bumoe Tarie join Partai Aceh. Thus, the

\footnotetext{
${ }^{7}$ Data Independent Election Commission Holland 2012

${ }^{8}$ FGD was held on May 30, 2015
}

(KIP) 
empowerment organization of ex GAM combatants and conflict victims through Cooperative of Bumoe Tarie initiated by the commander of Sagoe Tengku Chiek Di Moen Lhoek is driven by ideological moral motivation, maintaining lasting peace, economic, social and political consolidation of energy resources for ex combatants.

\section{INTEGRATION AND STABILITY OF BUMOE TARIE COOPERATIVE}

\section{Responsibilities of the Management and Effective Communication}

In FGD $^{9}$ with the board of the cooperative it is revealed that until today they are still committed to achieve their goals with the maintenance of palm oil plantation managed by Cooperatives of Bumoe Tari. Although what they do sometimes have not been successful, but as board member, they continue to seek opportunities that they might achieve.

$\mathrm{IR}^{10}$ as the chairman of the cooperative in an interview said, "I myself personally want to lead this cooperative if its main purpose is to help the communities so that they too can live more prosperous in this era of peace."

Of these commitments it is envisaged that the social orientation is more prominent than personal orientation. From this kind of commitment, the existence of plantations managed by the cooperative can run. They always communicate what they do with the members of the cooperative, both successful and unsuccessful activities. They also always make progress reports on the activities of the organization that they have done. In this regard, IR, the chairman of the cooperative with other managers said that:

"We always report to the board and members of cooperatives of all kinds of issues and activities of the cooperatives that I have done either successful or unsuccessful. For example, I always make proposals submitted to the government to get assistance program for palm oil plantation for our cooperative. I always convey to the members and other

\footnotetext{
${ }^{9}$ FGD conducted on May 5, 2015

${ }^{10}$ Interview with IR on 16 April 2015
}

managers".11

From this description it can be understood that communication and dissemination that are always done by IR, the chairman of the cooperative, to what he has done is a form of institutional management to sustain the trust of the members. Thus, the existence of the cooperative as a joint organization always get trust from the members and other managers. Aspects of care and effective communication of the board of the institution as part of the responsibility of the board can be considered as an important aspect for institutional stability.

\section{Leadership System}

In an FGD ${ }^{12}$ researchers also saw with their own eyes how the pattern of relationships deliberations took place between them. For example, when they discussed something. Each party could speak his mind freely. And the best opinion was taken. Usually they had informal but serious meeting. And in expressing opinions, it was not dominated by the commander. Even the commander did more hearing and occasionally just expressed an opinion. Even some peole argued his opinion. And the situation was normal and not uncomfortable when they had to argue with the commander. Finally, the best opinion would be taken by the forum.

Such pattern of leadership in sagoe certainly has very large effect on the organization of Bumoe Tari Cooperative. Even the cooperative itself can be up and running because of the leadership pattern. The trust of the members and the community to the cooperative is a reflection of the leadership pattern in the deliberation. In an $\mathrm{FGD}^{13}$ with the management of Bumoe Tari Cooperative of palm oil plantation, it is revealed that the pattern of leadership has brought the ease and effectiveness in

\footnotetext{
${ }^{11}$ FGD was held on May 5, 2015.

${ }^{12}$ FGD was held on May 5, 2015.

${ }^{13}$ FGD was held on May 5, 2015.
} 
managing the cooperatives that still pace the shortage.

They said that

... In fact, DI has a simple life, so that if there is misleading information about him, other people will deny it. He is an honest and responsible person, he respects others, he does not differentiate others' background so that there is no privilege of certain groups than others, he is democratic, he does not use command system in decision-making process of the organization. In doing things for other people, he is always sincere and trust worthy and he is always being friendly...

That was the view of the board of the Cooperative of Bumoe Tari towards DI's leadership style and lifesyle. This view is certainly very important and a magnet for others to get motivated to work according to each capacity and responsibilities. This leadership has been exemplary for management and other members to always be concerned with social responsibility and therefore to also have a decent life.

The leadership style has a very big influence on the morale of the management and members of the cooperative. So, although the cooperative is still deprived in terms of economic capital but they are very strong in terms of social and cultural capital. Thus, the existence of the organization can be maintained and run step by step.

\section{Subsidy from the government}

To sustain the activities of Bomeo Tari Cooperative of palm oil plantation, the managers always make a breakthrough programs and proposals submitted to the government. When BRR (Rehabilitation and Reconstruction Agency for Aceh and Nias) still existed in 2008, the cooperative management applied for aid but not accepted. It is as said by IR:

... To sustain the cooperative activities we ever asked for help from the provincial government in 2008 and BRR but not accepted...14 It turns out they not only asked help from BRR but also to theGovernment of

\footnotetext{
${ }^{14}$ Interview conducted on June 6, 2015
}

Aceh but both government-owned institution failed to provide assistance to the cooperative.

Even so they still do not get discouraged and keep trying to ask for help to the government to create programs tailored to the government's ability to help. IR as the chairman of the cooperative said:

... We continue to ask for help and to create programs to the government of Aceh related to palmoil plantation that we manage but mostly deadlocked. It actually will quickly succeed if the government seriously wants to help the community... ${ }^{15}$

So although they had not managed to get help from the government, but they kept asking assistance programs related to palm oil plantation that they manage. In their view, if the government is really serious about actually helping the people, it is an easy job, but in their opinion that the government is actually not serious to help the people. With the presence of palm oil plantation cooperative like Bumoe Tari, it has helped the government in implementing community empowerment. So, the government can work together to distribute capital to community cooperatives. It can happen if the government does have intention to put the center and orientation of development on the society.

After a long time they have tried to get help from the government, we eventually got government assistance from Aceh oil and gas fund. This information was obtained in an interview with IR:

... But then we got help from Aceh gas and oil funds and we could plant about 150 hectares. We have not distributed the land yet to the members to avoid any issues because it is not sufficient for all members. Of the 150 hectares of land, approximately 30 hectares have been fruitful... ${ }^{16}$

So they have been able to open a palm oil plantation of 150 hectares and the plantation has not been distributed to the

\footnotetext{
${ }^{15}$ Interview conducted on June 6, 2015

${ }^{16}$ Interview conducted on June 6, 2015
} 
members in the form of plantation plot to avoid conflict because the plantation is not enough to be distributed to all members. So, the plantation is still completely managed by the cooperative. And, the produces of the plantation have helped to subsidize the cooperative activities under certain restrictions.

\section{Financing By Sagoe}

In terms of the chronic shortage of funding in the cooperatives, it has always subsidized by the sagoe. Many cooperative activities are always supported financially by the sagoe aside from the government to finance the needs of the plantation and the poor that are assisted by the sagoe. While the financial resources of the sagoe itself as revealed in an $\mathrm{FGD}^{17}$ it is said that:

... My friends and I are trusted by the public to collect rubber latex. The rubber latex later we sell to proprietor or we take to Medan (North Sumatera Province Capital) directly. From this rubber latex trading business, once they can make a profit of 80 million per month for sagoe when the price of rubber latex is still expensive. We use the revenue to help a little-bit the cost of palm oil plantation, to help people in need in urgent matters such as sickness and meugang meat and sarong for orphans in Eid celebration...

From this description, it appears that the position and responsibility of sagoe in the cooperative management of palm oil plantation are in the fore front, not only to sustain the activities of palm oil plantation but also in terms of fulfilling the urgent needs of cooperative members.

Even according to their confession in the FGD ${ }^{18}$ sagoe has to spend almost approximately one billion every year to subsidize the plantation cooperative that is used to maintain the plantation, to support organizational needs and to support the needs of cooperative members.

In this regard, the situation in Cooperative of Bumoe the Tari was conveyed

\footnotetext{
${ }^{17}$ FGD was held on May 30, 2015

${ }^{18}$ FGD was held on May 5, 2015
}

by $\mathrm{MB}^{19}$ :.....Since the initiators are the people who have the authority like the commander of sagoe and others so that the application is easier...

What seemingly appeared above is that if the initiative to move a job done by people who have power and authority then the work will be carried out more easily. If there is any constraint faced in the field then they will have way out such as with what way, as what has been described by the initiators of palm oil plantation of Bumoe Tari Cooperative.

\section{CONCLUSION}

The ex combatants in SagoeTengku Chiek Di Moen Lhok put social reintegration in post-conflict as something significant to be done. So that the peace that has been achieved through an exhausting struggle can be well maintained so it is not only stable but also sustainable. The reintegration process is done through the efforts to guarantee and to improve the welfare of the ex GAM combatants and conflict victims. So, with a collective consciousness they designed their own welfare and also the conflict victims through a joint venture of palm oil plantation. In order for this effort systematically organized, they altogether facilitated collective work through cooperative, named Cooperative of Bumoe Tari.

Through this collective work, it is expected that the welfare is not only enjoyed by individuals but also enjoyed by both excombatants and conflict victims. Moreover, at the same time the local authorities showed no real program in an effort to prosper ex GAM combatants and conflict victims. Then, the elite of GAM combatants in Sagoe Tengku Chiek Di Moen Lhoek felt the call to do a moral responsibility towards ex GAM combatants, conflict widows, conflict orphans and other marginalized communities.

System of democratic leadership, solidarity and responsibility of the board framed with a GAM military-style command

\footnotetext{
${ }^{19}$ The interview was conducted on March 28, 2015
} 
management system lead the organization of palm oil Bumoe Tari Cooperative to survive and are able to encourage the improvement of the welfare of ex-combatants and conflict victims. This success is not only able to significantly reduce the amount of unemployment and poverty rate in North Aceh but the most important is the stability and peace remains well maintained.

\section{REFFERENCES}

Alvesson, M., \& Skolberg, K. (2000). Reflexive methodology, new vistas for qualitative research. London: Sage Publication.

Atkitson, P. (Ed.). (2001). Hanbook of Etnography. London: Sage Publication.

Blaikie, N. (2000). Designing social research. Cambridge: Polity Press.

Faisal, Sanapiah. (2003). Collection and analysis of data in qualitative research, the analysis of qualitative data. Jakarta: Rajawali.

Kell, T. (1995). The roots of Acehnese rebellion 1989 - 1992. New York: Cornell University Ithaca.

Miles, M. B., \& Haberman, A. M. (1992). Qualitative data and data analysis Jakarta: UI Press.

Moleong, Lexi J. (2000). Motodology of Qualitative Research. Bandung: Rosdakarya.
Nazaruddin, M. (2011). Politics Identity of Acehnese Resistance (Acehnese identity Reproduction Study By Elite GAM). Dissertation, Fisipol UGM Yogyakarta.

Nirzalin. (2012). Ulama and politics In Aceh, Exploring The Power Relation Between Teungku Dayah and State Apparatus. Yogyakarta: Pustaka Pelajar.

Nugroho, H. (2001). Money, Moneylenders and Debts In Java. Yogyakarta: Pustaka Pelajar.

Patton, M. Q. (1987). How to use qualitative methods evaluation. California: Sage Publications.

Reid, A. (2006). Verandah of violence the background to the Aceh problem. Singapore: Singapore University Press.

Sayuti, N. (2012). Economic Empowering For Ex- GAM Combatans and Community Post MoU-Helsinki. Aceh: Fisip Unimal

Thaib, L. (2002). Acheh's case, a historical study of the national movement for the independence of Acheh-Sumatra. Kuala Lumpur: University of Malaya Press.

Tiro, H. (1981). The price of freedom, the unfinished history. Sweden: Information Departement National Liberation Front Acheh Sumatra.

Tornquist, 0. (2011). Aceh, Democracy Role For Peace and Reconstruction. Yogyakarta: PCD

Press. 